\title{
Everyday Enchantments: Literacy and the Politics of Representation
}

\author{
MARY HAMILTON \\ Lancaster University
}

\begin{abstract}
This short paper refers back to the pre-conference presentation I gave at last year's (May, 2010) CSSE meeting in Montreal. It uses a contemporary example from everyday social practice to discuss the powers of literacy in social ordering.
\end{abstract}

It is July 2011 as I write from my home in the North West of England. I have been asked to summarise the presentation I gave to the CSSE pre-conference last summer in Montreal, which addressed the connections between literacy research, critical policy analysis and social action. In that presentation I focussed on the literacy artefacts associated with the accountability frameworks that so perplex and frustrate teachers in many educational contexts. I discussed in particular the Individual Learning Plan used in classrooms in England, and the ways in which it uncomfortably entangles both teachers and learners in policy initiatives that aim to reform practice.

ILPs are still important, but today I am glued to the television news and I want to write about a different example. I watch, in a state of over-excitement, a tense unfolding drama of mafia-like criminality. Rupert Murdoch's News International media empire is being laid bare in public, exposing complicity between journalists, the police and the political elite. Money has passed hands, favours have been granted and many kinds of communication about these activities are being probed by the parliamentary select committees and by political commentators. Extracts are presented from transcripts of conversations; there is talk of written notes, signatures, cheques and witness statements, letters from solicitors, emails and voicemails. Pages of newsprint and blogs detail the web of relationships and habits of working that make up what participants are calling a "culture" of phone hacking and deception, fear and hubris. Producers of newspapers, consumers and beneficiaries alike appear to have been enchanted by this culture, until they woke suddenly a few days ago and looked around at one another in horror and embarrassment. Everyone is scrambling to justify and explain why it all seemed so reasonable at the time.

It is a moment that Dorothy Smith might recognise and savour as a rare public revelation of the relations of ruling which structure our day to day experience and which are normalised within it (Smith 2005). As a student and researcher of literacy as social practice I can't help but notice the ways in which written texts in all their dazzling contemporary variety are actively ordering both the unfolding events and helping to reconstruct the history of what has taken place.

Since this is a story about the mass media and especially the life and death of England's best-selling tabloid newspaper, the News of the World, literacy is the very stuff under scrutiny. This is not literacy as it is often presented and discussed on front page news stories - as skills and standards, as a badge of failure or success - but literacy as part of social practice. That is, literacy as integral to the ways that people and institutions produce, circulate, read, display, 
argue over and generally make things happen through their actions with the written word. The issues of hidden, deleted and unread literacy artefacts are as prominent and powerful as the public revelation and creation of others. The investigative reporting that tracked down evidence over a period of years is one face of literacy. The plastic sacks of email printouts and documents lying apparently unopened and unexamined in police storage, the laptop tossed into the garbage and the file of damning evidence secreted in the solicitor's office are another. That power is exercised as much through discarding, deleting and denying knowledge as through the assertion of evidence, is a lesson that is not much taught in the literacy skills curriculum.

The dominant discourses of literacy encourage us to think about it in terms of skills possessed by individuals, as something identified with educational settings that can be measured by levels and tests of academic achievement. These discourses take our attention away from the wider and powerful everyday manoeuvres of reading and writing that happen between people, often apparently invisible to us, deeply embedded as they are in matters of feeling and value and profit. These manoeuvres are literacy as process and powerful actant - what Lesley Bartlett refers to as "literacy as verb" (Bartlett 2008). They tell us about how the original stories in the News of the World, were constructed collaboratively by journalists, editors and private investigators, and facilitated by the police. They show us the anger and resistance of voices unheard or misrepresented in these stories. They have led us to pore over court and parliament transcripts of speeches made and things unsaid, much reading between the lines and critical analysis.

Does all this seem a long way from the classroom, from the reading primer, the induction of a bilingual child into the world of creative writing? Do these events have anything to do with the diagnosis of reading difficulty, assessing progress, comprehension exercises, phonic decoding, worksheets and the rest of the paraphernalia of reading and writing instruction? How do they relate to the precious, special expertise of reading and writing teachers?

The approach of literacy as social practice would say the connections between what goes on in and out of the classroom are strong. Contemporary literacies are part of a complex fabric of media, threading through the many domains of our lives - work, play, politics, school, family, community. Schooled literacies are specialised, just as the forensic literacies of the courtroom are, but what goes on in each of these domains affects the others. We have to understand literacy in its many guises within this whole.

The purposes and applications of literacy can never be boxed away as separate concerns and while there is a time and place for reading instruction, it has to be located in the wider worlds of literacy within which children and their families participate. Likewise, teachers do not function in isolation. The classroom is also a workplace and alongside the reading books and whiteboards, teachers have their own literacy tasks to perform. They have to fill in the ILPs, attendance registers and report cards as part of their daily work and these documents travel out from the classroom to connect their work to wider structures of accountability. These performance indicators are used to create representations of education that in their turn are picked up as media stories of educational success and failure.

The paperwork carried out by teachers was my way in, last year, to discussing the powers of literacy in social ordering, but the example I have described above, that is galloping across the news media in my living room today, will do as well. We must not be enchanted by the narrow vision of literacy offered by testing regimes and accountability frameworks. The wider story is much, much more interesting and it is crucial to understanding - and intervening in - the workings of our textually-mediated social world. 


\section{References}

Bartlett, L. (2008). Literacy's verb: Exploring what literacy is and what literacy does. International Journal of Educational Development, 28(6), 737-753.

Smith, D. E. (2005). Institutional ethnography: A sociology for people. NY: AltaMira Press.

\section{Author Biography}

Mary Hamilton is Professor of Adult Learning and Literacy at Lancaster University and Associate Director of the Lancaster Literacy Research Centre. She has written extensively on policy, practice and everyday learning in adult literacy. She is co-author of a number of books including Local Literacies (with David Barton); Powerful Literacies (with Jim Crowther and Lynn Tett) and Changing Faces of Adult Literacy, Language and Numeracy: A Critical History (with Yvonne Hillier). 